Agnieszka Kacprzak

\title{
DETERMINANTS OF VERTICAL AND HORIZONTAL GENDER SEGREGATION IN THE WORKPLACE IN POLAND
}

\begin{abstract}
The aim of this article is to analyse factors influencing the level of horizontal and vertical occupational segregation in Poland. The results of qualitative and quantitative surveys conducted among Polish employees are investigated. The data are taken from a project on employee perspectives on corporate social responsibility. Ninety individual depth interviews (IDI) with participants from 22 sectors of the economy and 1000 computer-assisted telephone interviews (CATI) on a representative sample of Polish employees were carried out. A number of variables associated with respondents' socio-demographic status, the characteristics of respondents' organisations, and internalised values and norms, were analysed. The findings suggest that the vast majority of the observed examples of discrimination originate from the cultural values and norms of Polish society, which decision-makers and employees have internalised in the early stages of the socialisation process.
\end{abstract}

Keywords: gender discrimination, vertical segregation, horizontal segregation, Poland.

\section{Introduction}

Discrimination based on employee demographic characteristics is a manifestation of unethical behaviour by companies. One form of this is the assessment of certain employees as better or worse solely because of their gender (Maas \& Torres-Gonzalez 2011). Gender discrimination can take many different forms. These include employment discrimination, which prioritises the recruitment of male over female candidates with comparable qualifications and professional characteristics. Another manifestation of discrimination is limiting women's access to training in order to raise 
professional qualifications, and also the differences in wage and non-wage benefits that exist between men and women working in the same profession and under the same conditions (Ngo et al. 2003). Finally, an important manifestation of gender discrimination is horizontal and vertical segregation in the workplace.

Vertical segregation means limiting promotion and career opportunities. Many studies have shown that women are less likely to be promoted than their male colleagues who have the same qualifications (Blau \& Devaro 2007, Hau Siu Chow \& Crawford 2004, Lyness \& Heilman 2006, Yap \& Konrad 2009). Women also constitute only a small percentage of CEOs in most countries that belong to the Organisation for Economic Cooperation and Development (OECD), despite the fact that they are as well educated as men and have actively participated in the labour market for several decades (Manpower 2008).

Horizontal segregation identifies situations in which certain economic sectors, professions, or organisational departments are dominated by people of one sex. According to European studies, the most feminised professions in the EU are: shop assistants and store demonstrators, domestic and related helpers, cleaners and launderers, and personal care and related workers. In turn, the most masculinised include: motor vehicle drivers, building frame and related trade workers, and managers of small enterprises (Bettio \& Verashchagina 2009). Women are twice as likely to be employed in low-paid service-related jobs, and men are ten times as likely to work in highly-paid technical professions (Langdon \& Klomegah 2013).

Let us now look at the level of horizontal and vertical segregation in Poland in light of current research. The Gender Empowerment Measure for Poland is not impressive - women represent only $36 \%$ of legislators, senior officials, and managers (Tomlinson 2011). This is despite the fact that more women than men in Poland undergo tertiary education (83\% versus 58\%). In turn, the Gender Gap Index places Poland in $53^{\text {rd }}$ position in the world. This indicator measures gender equality in education, health, the economy, and politics. As regards the component relating to economic equality, Poland is in $72^{\text {nd }}$ place with a score of 0.65 (where 0 is no equality, and 1 full gender equality). In turn, the indicator showing the ability of women to rise to positions of enterprise leadership is 3.92 (on a scale of $1-7$, where 7 means equal opportunities) (Hausmann et al. 2012).

When it comes to horizontal segregation, the most masculinised professions in Poland are those associated with construction and mining, and professional drivers (where the proportion of women is below $2 \%$ ). 
The most feminised industries are, in turn, clothing, child care, and nursing (over $95 \%$ women). Only $14 \%$ of economically active people in Poland work in professions with a more or less equal proportion of men and women (Czarnik \& Turek 2012).

\section{Factors Affecting the Level of Gender Discrimination in the Workplace}

The level of gender discrimination in the workplace is affected by a large number of internal and external factors. These include variables related to employee socio-demographic status (age, marital status, number of children, education), the characteristics of the organisation (number of employees, type of business, seniority in the company), and internalised values and norms (cultural stereotypes, self-categorisation, self-stereotyping).

\section{Employee Socio-demographic Status}

With regard to employee age, research shows that discrimination against women is more often observed by older workers. A survey of American college graduates shows that women in their 40s earn $30 \%$ to $45 \%$ less per hour than men, while for those in their 20 s the difference is $5 \%$ to $10 \%$ (Weinberger 2011). The earnings and promotion opportunities of older women may be affected by more career breaks related to raising children and less willingness to work overtime due to childcare and household responsibilities (Kirchmeyer 2002).

The results also reveal a relationship between discrimination in the workplace and an employee's marital status and the number of children they have. Because in most societies men are seen as economic providers, the relationship between the level of wages and marital status is reversed for women and men. Married men earn more than unmarried men, while single women earn more than married women (Witkowska 2013). Also, having children only negatively affects women's careers, not men's (Kurland 2001). Research on Danish CEOs has shown that $13 \%$ of female CEOs have three or more children, while for men the figure is $30 \%$ (Smith, Smith \& Verner 2013).

If we look at another socio-demographic factor - education, it should be noted that a higher standard of education is associated with higher earnings for both sexes, but in the case of men this relationship is stronger than it is for women. Women are often discouraged from an early age by their families, teachers, and communities to choose fields of study related to technology 
and science, which often provide high salaries (Giapponi \& McEvoy 2005, Langdon \& Klomegah 2013).

This brings us to the first research hypothesis, which is:

H1: Employees' perceptions of their organisation as discriminatory against women will be affected by socio-demographic factors, such as age, marital status, number of children, and education.

\section{Characteristics of the Organisation}

The level of gender discrimination depends on the size of the company. The smaller the organisation, the greater the gender inequality. This is due to the fact that workers in large companies know less about other members of the organisation. Larger companies also often have bureaucratic procedures associated with a higher level of ethical formalism and utilitarianism (Schminke 2001).

If we look at the type of business, it is worth considering what the level of gender discrimination looks like in manufacturing, retail, and service companies. In most countries, manufacturing employs a majority of men, while in service and retail industries the ratios are more balanced. According to research, in organisations with a predominance of men, employee self-promotion is expected, and gender stereotypes are strongly present women have a weaker network of contacts, earn less, and are less likely to be promoted (Martin 2011).

It is also possible to assume the existence of a relationship between organisational tenure and the level of gender discrimination perceived by the employee. The longer the experience, the more gender inequality is noticed, because employees with longer work experience have collected more data (Ngo et al. 2003).

Therefore, the second research hypothesis is stated as follows:

H2: Employees' perceptions of their organisation as discriminatory against women will be affected by organisational factors, such as the number of employees, type of business, and duration of employment in a company.

\section{Internalised Values and Norms}

Gender stereotypes assume that there are certain psychological traits of each gender, and also include beliefs about the typical social roles of men and women (Powell \& Greenhaus 2010). These stereotypes are structured according to two dimensions: agency or competence associated with men, and communion or warmth connected with women (Fiske et al. 2002, Guimond et al. 2006). 
Regarding the impact of stereotypes on vertical segregation, previous research on this topic has shown that the majority of managers believe that men are more likely than women to have characteristics associated with the achievement of success in a managerial position (Schein 1973, 1975). The consequence of this is that women are less likely than men to be leaders of a group, because male focus on task achievement is seen as more important in being a leader than female interpersonal skills (Acker 2011, Carli \& Eagly 1999). Discrimination against women in access to managerial positions is also the result of such beliefs as: women are more interested in family than career; are less educated than men; put less effort into their work; and are not able to fight for their interests (Falkenberg \& Boland 1997, Martin 2011).

Cultural stereotypes are also a cause of horizontal segregation in the labour market and within individual organisations. It is believed that men and women show different preferences for which professions they want to choose in life, and that these preferences are shaped in the process of socialisation long before entering the labour market (Bettio \& Verashchagina 2009, England 2005, Kane \& Sanchez 1994).

One of the most important causes of vertical and horizontal segregation in the workplace is self-categorisation and self-stereotyping. According to self-categorisation theory (Turner et al. 1987), self-perception is partly based on assigning oneself characteristics resulting from group stereotypes (Biernat, Vescio \& Green 1996, Guimond et al. 2006). Self-stereotyping takes the form of depersonalisation, which results in a person seeing themselves rather as a model representative of a social group with which to identify than as a unique individual (Latrofa et al. 2010).

Research shows that men are less likely to self-stereotype than women, and do so in a less resolute and consistent way (Biernat et al. 1996, Latrofa et al. 2010). According to research, people from minority groups in terms of numbers and lower social status are more likely to self-stereotype (Latrofa et al. 2010). Women are considered a lower social status group, and therefore assign themselves typically "feminine" qualities to a greater degree, while men are more likely to perceive themselves as unique individuals (Cadinu \& Galdi 2012, Ely 1995).

The stronger the tendency of women than men to self-stereotype also results in women's self-discrimination in access to promotion. As studies of Danish managers have shown, women in high positions display stronger gender stereotypes than men (Neergaard et al. 2008). In turn, the research of Smith, Smith \& Verner (2013) shows that the higher the proportion of 
women on the board of a company, the greater the chance of promotion to it for men.

This allows for the formation of the research question (Q1), which is:

Q1: Employees' perceptions of their organisation as discriminatory against women will be affected by internalised values and cultural norms, such as cultural stereotypes, self-categorisation, and self-stereotyping.

\section{Data and Methods}

The research on gender discrimination issues in the workplace in Poland was part of a larger research project whose objective was to analyse the challenges of corporate social responsibility from the perspective of employees ${ }^{1}$. The study was carried out in two stages: qualitative and quantitative. The first phase consisted of 90 in-depth interviews (IDI) with employees representing various sectors of the Polish economy, deliberately chosen on basis of gender, place of residence, size of organisation, age, and job. The explorative objective of this stage was to better understand the issues discussed and collect examples of particular organisational phenomena. The interview scenario was partly structured and non-standardised, encouraging participants to speak freely on issues raised. One of the 12 main questions (in conjunction with 6 auxiliary questions) was related to the topic of discrimination based on gender in the workplace. The second phase of the research included a quantitative survey on a nationwide representative sample of 1,000 employees. The sample selection took place using the random-quota method. The studies were carried out by computer-assisted telephone interviews (CATI). The items in the questionnaire were based on the typical five-level Likert format from "strongly agree" to "strongly disagree". The collected data was analysed with NVIVO (qualitative stage) and SPSS (quantitative stage).

This research approach made it possible to investigate the phenomena analysed from different methodological perspectives. In order to ensure reliability, the triangulation of research methods (using qualitative and quantitative techniques) and triangulation of data and researchers (research by a multiple-member team and the use of competent judges) was applied (Denzin 1978, Jick 1979).

${ }^{1}$ Corporate Social Responsibility - Employee Perspective, a project funded by the European Union Human Capital Operational Programme (WND-POKL.02.01.02-00-012/10). 


\section{Research Results}

\section{Horizontal Segregation}

To measure horizontal segregation, the quantitative survey used the statement "Most prestigious positions in my company are held by men". $55.0 \%$ of the respondents agreed with this statement, while $33.0 \%$ held the opposite view, which confirms the existence of horizontal segregation in Polish companies.

Regarding respondent characteristics, horizontal segregation was more likely to be noted by men, older people, less educated people, and those occupying managerial positions and with long service in the company (Table 1). A statistically significant relationship was also observed between the level of horizontal segregation and company characteristics: the larger the company, the more employees noticed its manifestations. This also occurred much more frequently in manufacturing than in retail and service companies $(69.1 \%$ vs $50.4 \%)$.

Table 1. Relationships between the Statement: "Most prestigious positions in my company are held by men" and the Characteristics of Respondents and Their Organisations

\begin{tabular}{|c|c|c|c|c|c|}
\hline \multirow{2}{*}{\multicolumn{2}{|c|}{ Independent Variable }} & \multirow{3}{*}{$\begin{array}{c}\begin{array}{c}\text { Horizontal } \\
\text { Segregation } \\
\text { Level }(\%)^{\mathrm{a}}\end{array} \\
35.4\end{array}$} & \multicolumn{3}{|c|}{ Pearson Chi Square Test } \\
\hline & & & Volup & $d f$ & $n$ \\
\hline \multirow[t]{2}{*}{ Gender } & Female & & \multirow[t]{2}{*}{161.907} & \multirow[t]{2}{*}{4} & \multirow[t]{2}{*}{0.0001} \\
\hline & Male & 67.0 & & & \\
\hline \multirow[t]{5}{*}{ Age } & $\leq 24$ & 50.0 & \multirow[t]{5}{*}{28.190} & \multirow[t]{5}{*}{16} & \multirow[t]{5}{*}{0.030} \\
\hline & $25-34$ & 53.3 & & & \\
\hline & $35-44$ & 49.0 & & & \\
\hline & $45-54$ & 58.6 & & & \\
\hline & $\geq 55$ & 64.6 & & & \\
\hline \multirow[t]{3}{*}{ Education } & Primary & 69.4 & \multirow[t]{3}{*}{29.434} & \multirow[t]{3}{*}{8} & \multirow[t]{3}{*}{0.0001} \\
\hline & Secondary & 52.7 & & & \\
\hline & Tertiary & 48.6 & & & \\
\hline \multirow{2}{*}{$\begin{array}{l}\text { Marriage } \\
\text { or domestic } \\
\text { partnership }\end{array}$} & Yes & 53.8 & \multirow[t]{2}{*}{6.709} & \multirow[t]{2}{*}{4} & \multirow[t]{2}{*}{0.152} \\
\hline & No & 56.0 & & & \\
\hline
\end{tabular}


Table $1 \mathrm{cnt}$ 'd

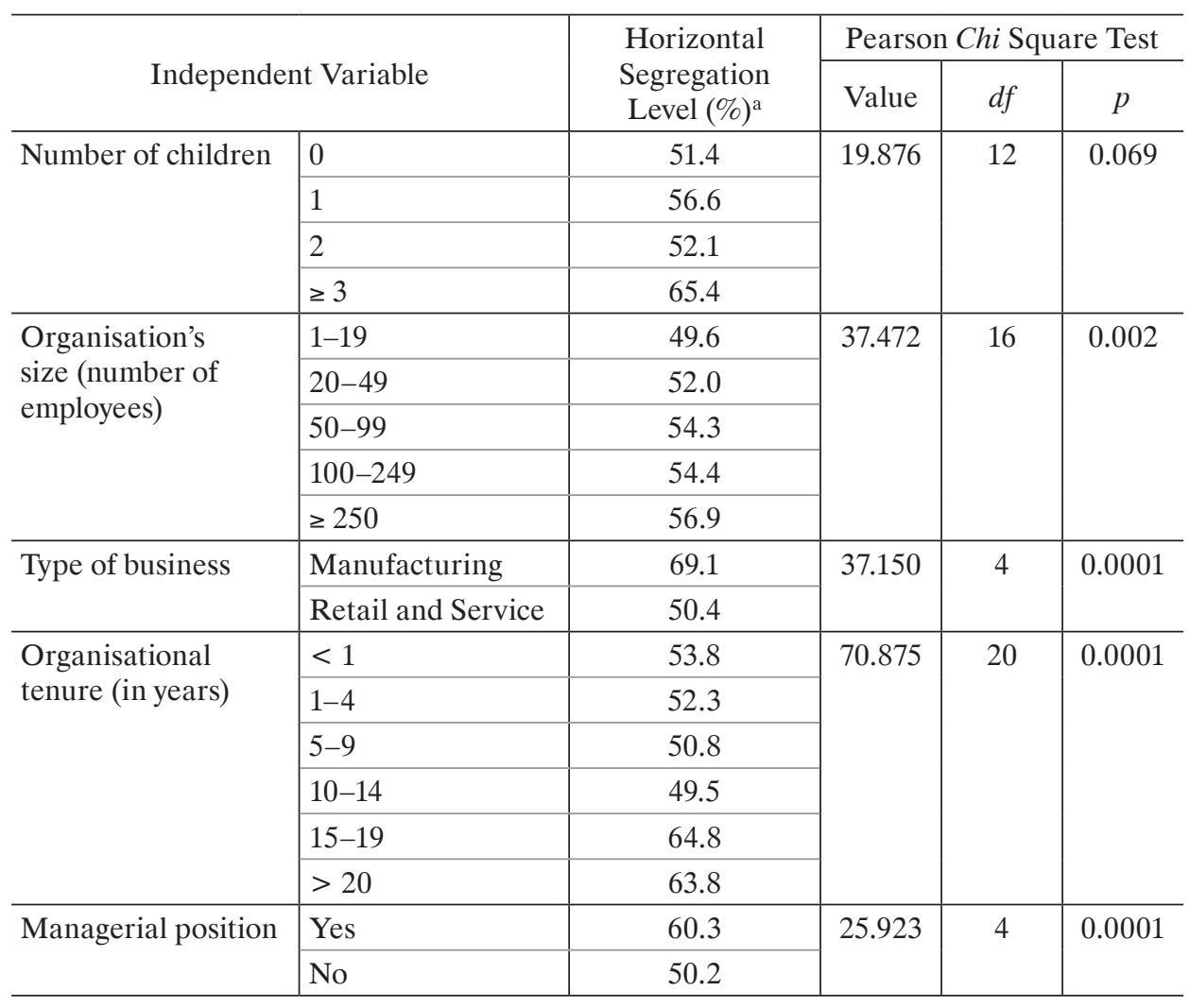

$N=1000, p=0.005 ;$ a percentage of "agree" and "strongly agree" answers.

Source: author's own research.

When it comes to subjective determinants of horizontal segregation in the workplace, the research material included many examples of cultural stereotypes associated with the perception of the typical characteristics and social roles of women and men.

Among employees in manufacturing, there is a stereotype that men should deal with technically advanced products, and women where an attractive visual design is most important.

Women [are] in the bag department because it is much easier for them to express themselves when it comes to introducing a new model or a new design compared to a computer power supply, where it is hard to talk about beauty, and where everything has to work. And I know that often in the manufacturing sector 
they choose women as product managers for more feminine product groups, where technical knowledge and equipment are less advanced.

(computer manufacturing, $\geq 250$ employees, male, 35-44 years old, manager)

Women were also believed to be unfit for work associated with frequent business trips, due to the fact that they have to deal with children and family.

In sales it's hard because you have to go to wholesalers, and there are not many women (...). Just in terms of these different journeys, being in sales, well, if you have a child, it's hard to leave.

(computer manufacturing, $\geq 250$ employees, male, 26-34 years old, manager)

Another stereotype is the image of women as neater, more congenial, and more able to get along with people than men, and therefore more suitable for customer service departments. The exception is technical sectors, where customers are served by men. According to our respondents, this is due to the fact that women do not possess the necessary technical knowledge about these products to advise customers.

Women deal with customer service, for instance. Rarely is customer service dealt with by guys; if it is, the guys are sent to highly technical customers. A customer who is a manufacturer of building materials will talk completely differently to a guy, because it's the guys who do repairs, because guys are better at dirty or technical stuff. (...) So here I see that there are much more women dealing with customer service. They're nicer, they look better, they're more neat, fragrant and... and this is a job often dedicated just to, just for women. Life shows this.

(advertising, <250 employees, male, 35-44 years old, manager)

I had a funny situation and I also heard that the girls have encountered it. A guy comes and says: I won't talk to a woman, no chance. I know better than you.

(furniture, $\geq 250$ employees, woman, $\leq 34$ years old)

Another sector in which customers prefer to be served by men is the financial and insurance sector. One of the interviewees noted that her company's customers were more serious with men and had greater confidence in them than women.

It's the financial and insurance industry, and customers often prefer to talk to a man. (...) Men are treated more seriously (...). They are just perceived better by customers.

(financial and insurance activities, $\geq 250$ employees, woman, $\leq 34$ years old)

Another subjective determinant of horizontal segregation is women's self-categorisation. Many female participants in the study presented views consistent with the stereotypical perception of women as the "weaker sex", 
not suitable for tasks requiring not only physical strength but also technical skill. The result is that women self-discriminate.

I don't know if a woman who volunteered to work as an operator would be accepted. There is this view now that it should always be men. Because it's machinery.

(food manufacture, $\geq 250$ employees, woman, $\leq 34$ years old)

Here, unfortunately, there are only men, because the work requires strength, it's difficult. Carrying those heavy carcasses, it's hard work, for women it is. We're too weak to do it.

(food manufacture, $<250$ employees, woman, 45-54 years old, manager)

Some female participants considered as completely normal the fact that women performed work associated with lower wages, which they justified, inter alia, by the fact that men are the breadwinners.

In fact, there are probably more women salespeople than men. There are very few men. There are reasons for this: because men want to earn more, and here the wages aren't that high. They're only sufficient for women.

(retail, $<250$ employees, woman, $\geq 55$ years old)

In turn, female respondents in the financial and insurance sectors believe that women are made for dull and monotonous office work, which men quickly become bored with because they seek greater challenges in their professional lives.

$90 \%$ of our staff are women and always have been. (...) Men get bored, usually quite quickly, and prefer to have another job, not just one where they're sitting at a desk and clicking on something on the computer, or shuffling papers. After a year, the job becomes too monotonous. Men say no thanks and women say yes please.

(financial and insurance activities, $\geq 250$ employees, woman, $\leq 34$ years old)

\section{Vertical Segregation}

To measure vertical segregation, the statement "Most of the managers in the company where I work are men" was used in the quantitative survey. Men agreed with the statement much more frequently than women $(66.2 \%$ vs $31.5 \%$ ). Also significant was the relationship between vertical segregation and employee education - its manifestations were more often observed by people with basic education (Table 2). Another factor influencing the observation of vertical segregation was length of service in the company - the longer the period of employment, the greater the percentage of staff noting vertical segregation in their company. Employees occupying 
managerial positions noted barriers to women's advancement in their company more often than people in lower positions. Vertical segregation was most frequently observed by those employed in large companies, and least frequently by those employed in medium-sized enterprises. A difference also emerged with regard to the type of company - in manufacturing, $67.1 \%$ of employees believe that men dominate in leadership positions in their organisations, while in retail and service companies $48.0 \%$ of surveyed employees are of this opinion.

Table 2. Relationships between the Statement: "Most of the managers in the company where I work are men" and the Characteristics of Respondents and Their Organisations

\begin{tabular}{|c|c|c|c|c|c|}
\hline \multirow{2}{*}{\multicolumn{2}{|c|}{ Independent Variable }} & \multirow{3}{*}{$\begin{array}{c}\text { Vertical } \\
\begin{array}{c}\text { Segregation } \\
\text { Level }(\%)^{\mathrm{a}}\end{array} \\
31.5\end{array}$} & \multicolumn{3}{|c|}{ Pearson Chi Square Test } \\
\hline & & & \multirow{3}{*}{$\begin{array}{c}\text { Value } \\
155.545\end{array}$} & \multirow{3}{*}{$d f$} & \multirow{3}{*}{$\begin{array}{c}p \\
0.0001\end{array}$} \\
\hline \multirow[t]{2}{*}{ Gender } & Female & & & & \\
\hline & Male & 66.2 & & & \\
\hline \multirow[t]{5}{*}{ Age } & $\leq 24$ & 53.6 & \multirow[t]{5}{*}{17.531} & \multirow[t]{5}{*}{16} & \multirow[t]{5}{*}{0.352} \\
\hline & $25-34$ & 48.0 & & & \\
\hline & $35-44$ & 48.8 & & & \\
\hline & $45-54$ & 57.4 & & & \\
\hline & $\geq 55$ & 62.4 & & & \\
\hline \multirow[t]{3}{*}{ Education } & Primary & 65.9 & \multirow[t]{3}{*}{41.976} & \multirow[t]{3}{*}{8} & \multirow[t]{3}{*}{0.0001} \\
\hline & Secondary & 56.2 & & & \\
\hline & Tertiary & 41.2 & & & \\
\hline \multirow{2}{*}{$\begin{array}{l}\text { Marriage } \\
\text { or domestic } \\
\text { partnership }\end{array}$} & Yes & 52.1 & \multirow[t]{2}{*}{3.436} & \multirow[t]{2}{*}{4} & \multirow[t]{2}{*}{0.488} \\
\hline & No & 53.1 & & & \\
\hline \multirow[t]{4}{*}{ Number of children } & 0 & 46.3 & \multirow[t]{4}{*}{25.573} & \multirow[t]{4}{*}{12} & \multirow[t]{4}{*}{0.012} \\
\hline & 1 & 57.8 & & & \\
\hline & 2 & 54.3 & & & \\
\hline & $\geq 3$ & 54.8 & & & \\
\hline \multirow{5}{*}{$\begin{array}{l}\text { Organisation's } \\
\text { size (number of } \\
\text { employees) }\end{array}$} & $1-19$ & 50.7 & \multirow[t]{5}{*}{38.746} & \multirow[t]{5}{*}{16} & \multirow[t]{5}{*}{0.001} \\
\hline & $20-49$ & 52.9 & & & \\
\hline & 50-99 & 48.9 & & & \\
\hline & $100-249$ & 53.0 & & & \\
\hline & $\geq 250$ & 53.1 & & & \\
\hline
\end{tabular}


Table 2 cnt'd

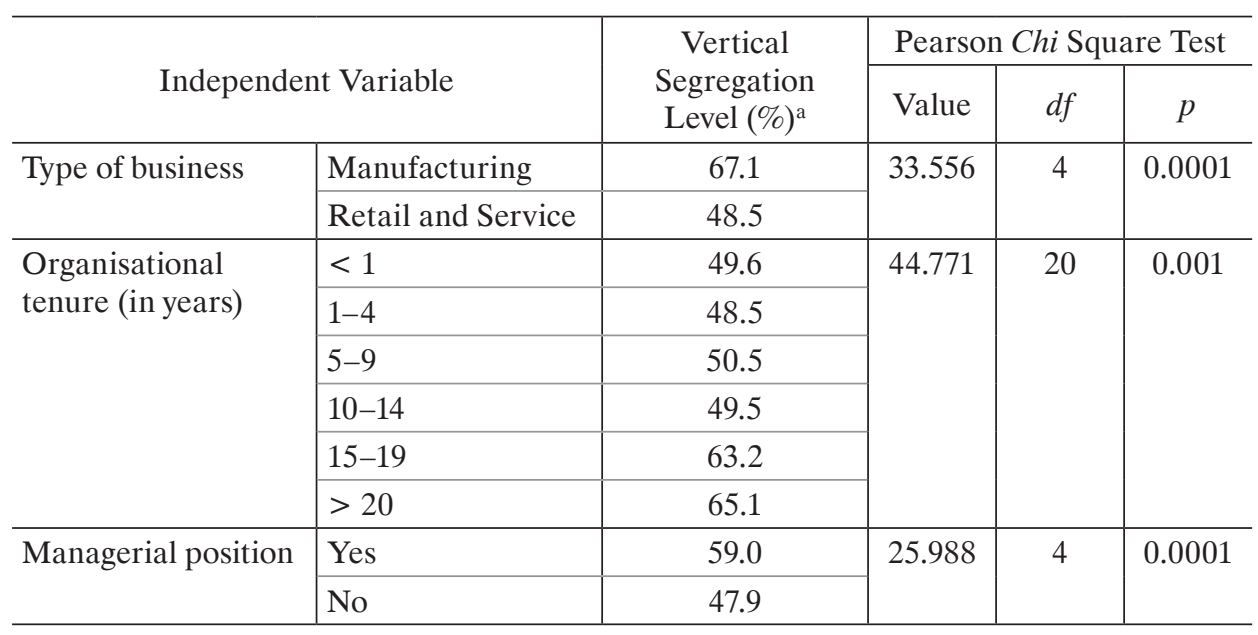

$N=1000, p=0.005 ;$ a percentage of "agree" and "strongly agree" answers.

Source: author's own research.

The material derived from the qualitative research included stereotypes associated with the belief that leadership roles are reserved for men as well as various examples of the stereotypical view that female characteristics are not conducive to women taking up managerial positions. These stereotypes were especially evident in sectors employing mainly men (e.g. manufacturing companies). Participants believed that a woman would not cope in managing a team of male workers as she would not be able to maintain discipline in the workplace.

99.9\% [of managers] are guys. (...) However, this is heavy industry, and it's believed that a woman can't handle it mentally, there is often swearing (...). There's constant showing off amongst men. And proving that you can do at least as much as they do.

$$
\text { (metal manufacturing, } \geq 250 \text { employees, woman, } \geq 55 \text { years old) }
$$

[Men] are able to have greater authority because we work with plumbing and construction teams and so on. That's how it is, unfortunately. It's difficult for me to exert pressure on a plumber, a builder, or someone like that, but I think a man would have it easier.

$$
\text { (real estate, }<250 \text { employees, woman, } \leq 34 \text { years old) }
$$

This stereotypical perception of women is also reflected in the idea that they cannot handle difficult situations, which, according to one of our female 
interviewees, explains the lack of women in senior management positions in her company.

Women are immediately in a weaker position. The overall assessment is that a man can handle embarrassing situations better; he can deal with them better.

(real estate, $<250$ employees, woman, 45-54 years old, manager)

As in the case of horizontal segregation, the stereotype of women as homemakers reappeared: due to their involvement in childcare and household responsibilities, they are not able to dedicate as much time to their career as a man can, and are therefore less likely to be promoted.

Maybe it's related to family responsibilities. That women just need more time for the home. Therefore, they are not willing to take up positions that require greater commitment.

$$
\text { (architecture, }<250 \text { employees, woman, } \geq 55 \text { years old) }
$$

\section{Discussion}

With regard to socio-demographic determinants, the results of this study confirm the link between a worker's age and their perceived level of horizontal and vertical segregation in the workplace. Older workers observed this more frequently. Also statistically significant was the effect of education, but in reverse than that assumed in the literature (Langdon \& Klomegah 2013, Witkowska 2013). More gender discrimination was acknowledged by respondents with lower than with higher education. The marital status of a respondent turned out to have no impact on their perception of gender discrimination in the workplace, while having a child had an effect on vertical segregation - childless workers observed it significantly less frequently than those with children, which is consistent with the results of other surveys (Kurland 2001, Smith, Smith \& Verner 2013). Therefore, the first research hypothesis (H1) was partly supported.

In the present study, all the analysed organisational factors (size of company, type of business, length of work experience) affected the perceived level of both horizontal and vertical discrimination in the workplace. Accordingly, the second research hypothesis (H2) was positively verified. Other results were reported by Ngo et al. (2003). Those authors did not confirm the hypothesis that the size of the organisation, position within the organisation, and length of work experience are relevant to the level of perceived discrimination on grounds of gender in their study. Interestingly, the relationship between company size and the level of perceived horizontal 
and vertical segregation proved to be the opposite to that assumed in the literature (Ngo et al. 2003, Schminke 2001). Namely, it was significantly more frequently observed by employees in large as opposed to small and medium-sized firms. This may indicate that in Poland even large organisations do not run equality campaigns or develop policies to prevent discrimination on grounds of gender.

Among the causes mentioned for horizontal and vertical discrimination in the workplace (Q1), one can find many examples of stereotypes about the characteristics of men and women, and the typical roles that each sex should play in society, which function in Polish culture. Respondents presented strong convictions about which professions are suitable for men (technical, requiring physical strength, better paid), and for women (monotonous, requiring human contact, less well paid). In the analysed research material there were also numerous examples of self-discrimination by women resulting from their self-categorisation as representatives of the weaker sex, with lower professional competence than men, obliged to put more effort into performing childcare and household responsibilities. The results of research conducted in other countries also show that cultural stereotypes underlie the selection by men and women of different educational paths and careers (Valentova, Krizova \& Katrnak 2007).

As reasons for the lack of women in leadership positions, respondents mostly used stereotypes based on the idea that women lack the appropriate traits to deal with this type of job. These results are consistent with other studies, which also observed that women are often believed to lack the characteristics needed to be a leader (Carli \& Eagly 1999, Efthymiou, Vitsilakis \& Cakis 2012, Schein 1973, 1975, Yap \& Konrad 2009).

In conclusion, it should be noted that the gender discrimination in the workplace appearing in this study hardly ever took the form of direct discrimination resulting from official company policy. There were, however, many examples of women's self-discrimination and conformity of the positions of men and women to gender stereotypes. At this point, we may draw the conclusion that the vast majority of observed examples of discrimination were rooted in the values and cultural norms of Polish society, which policy-makers and workers internalise in the early stages of the socialisation process. This conclusion is consistent with the results of studies conducted in other countries, which also indicate that discrimination against women in the workplace is largely the result of employee gender stereotypes and cultural norms related to gender which affect the culture of 
the organisation and the practices it employs (Efthymiou, Vitsilakis \& Cakis 2012, Sappleton \& Takruri-Rizk 2008).

\section{Limitations and Further Research}

The first limitation of this study is the use in the quantitative research of single-statement indicators to diagnose the degree of perception of horizontal and vertical segregation in the workplace. This was due to the magnitude of the topics covered in the study and the organic space devoted to issues of gender discrimination. Further research in this area should include the use of more complex indicators to measure the level of segregation by gender in the workplace and their correlation with the socio-demographic determinants of respondents and the characteristics of their organisations.

The second limitation is that the analysis of the impact of cultural stereotypes and women's self-categorisation was carried out only on the basis of qualitative data. It would be interesting to conduct adequate quantitative research on a representative sample of respondents to check what the actual scale of these two phenomena is and their correlation with the level of discrimination against women in the workplace.

\section{Bibliography}

Acker, J. (2011) "Theorizing Gender, Race and Class in Organizations" in E. Jeanes, D. Knights and P. Martin (eds) Handbook of Gender, Work and Organization. Chichester: Wiley.

Bettio, F. and Verashchagina, A. (2009) Gender Segregation in the Labour Market: Root Causes, Implications and Policy Responses in the EU. Luxembourg: European Commission's Expert Group on Gender and Employment.

Biernat, M., Vescio, T. and Green, M. (1996) "Selective Self-stereotyping". Journal of Personality and Social Psychology 71 (6): 1194-1209, http://dx.doi.org/10.1037/00223514.71.6.1194.

Blau, F. D. and Devaro, J. E. D. (2007) "New Evidence on Gender Differences in Promotion Rates: An Empirical Analysis of a Sample of New Hires". Industrial Relations 46 (3): 511-50, http://dx.doi.org/10.1111/j.1468-232X.2007.00479.X.

Cadinu, M. and Galdi, S. (2012) "Gender Differences in Implicit Gender Self-categorization Lead to Stronger Gender Self-stereotyping by Women than by Men". European Journal of Social Psychology 42: 546-51, http://dx.doi.org/10.1002/ejsp.1881.

Carli, L. and Eagly, A. (1999) "Gender Effects on Social Influence and Emergent Leadership" in G. Powell (ed.) Handbook of Gender and Work. Thousand Oaks, CA: SAGE Publications. 
Czarnik, S. and Turek, K. (eds) (2012) Aktywność zawodowa Polaków. Praca zawodowa. Wyksztatcenie. Kompetencje [The economic activity of Poles. Professional work. Education. Skills]. Warsaw: Polish Agency for Enterprise Development.

Denzin, N. K. (1978) Sociological Methods. A Sourcebook. New York: McGrew-Hill.

Efthymiou, I., Vitsilakis, C. and Cakis, D. (2012) "Horizontal and Vertical Gender Segregation in the ICT Sector: A Greek Case Study". Journal of Critical Studies in Business and Society 3 (1): 77-111.

Ely, R. (1995) “The Power in Demography: Women's Social Constructions of Gender Identity at Work". Academy of Management Journal 38 (3): 589-634, http://dx.doi. org/10.2307/256740.

England, P. (2005) "Gender Inequality in Labor Markets: The Role of Motherhood and Segregation”. Social Politics 12 (2): 264-88, http://dx.doi.org/10.1093/sp/jxi014.

Falkenberg, L. E. and Boland, L. (1997) "Eliminating the Barriers to Employment Equity in the Canadian Workplace". Journal of Business Ethics 16 (9): 963-75, http://dx.doi. org/10.1023/A:1017995522325.

Fiske, S. T., Cuddy, A. J. C., Glick, P. and Xu, J. (2002) "A Model of (Often Mixed) Stereotype Content: Competence and Warmth Respectively Follow from Perceived Status and Competition". Journal of Personality and Social Psychology 82 (6): 878-902, http://dx.doi.org/10.1037//0022-3514.82.6.878.

Giapponi, C. C. and McEvoy, S. A. (2005) "The Legal, Ethical, and Strategic Implications of Gender Discrimination in Compensation: Can the Fair Pay Act Succeed where the Equal Pay Act has Failed?". Journal of Individual Employment Rights 12 (2): 137-50, http://dx.doi.org/10.2190/8733-70w7-3576-6823.

Guimond, S., Chatard, A., Martinot, D., Crisp, R. and Redersdorff, S. (2006) "Social Comparison, Self-stereotyping, and Gender Differences in Self-construals". Journal of Personality and Social Psychology 90 (2): 221-42, http://dx.doi.org/10.1037/00223514.90.2.221.

Hau Siu Chow, I. and Crawford, R. B. (2004) "Gender, Ethnic Diversity, and Career Advancement in the Workplace: The Social Identity Perspective". SAM Advanced Management Journal 69 (3): 22-31.

Jick, T. D. (1979) "Mixing Qualitative and Quantitative Methods: Triangulation in Action". Administrative Science Quarterly 24: 602-11, http://dx.doi.org/10.2307/2392366.

Kane, E. W. and Sanchez, L. (1994) "Family Status and Criticism of Gender Inequality at Home and at Work". Social Forces 4: 1079, http://dx.doi.org/10.2307/2580293.

Kirchmeyer, C. (2002) "Gender Differences in Managerial Careers: Yesterday, Today, and Tomorrow". Journal of Business Ethics 37 (1): 5-24, http://dx.doi. org/10.1023/a:1014721900246.

Kurland, N. B. (2001) "The Impact of Legal Age Discrimination on Women in Professional Occupations". Business Ethics Quarterly 11 (2): 331, http://dx.doi. org/10.2307/3857752.

Langdon, D. and Klomegah, R. (2013) "Gender Wage Gap and Its Associated Factors: An Examination of Traditional Gender Ideology, Education, and Occupation". International Review of Modern Sociology 39 (2): 173-203.

Latrofa, M., Vaes, J., Cadinu, M. and Carnaghi, A. (2010) "The Cognitive Representation of Self-stereotyping”. Personality and Social Psychology Bulletin 36 (7): 911-22, http:// dx.doi.org/10.1177/0146167210373907. 
Lyness, K. S. and Heilman, M. E. (2006) "When Fit Is Fundamental: Performance Evaluations and Promotions of Upper-level Female and Male Managers". Journal of Applied Psychology 91 (4): 777-85, http://dx.doi.org/10.1037/6021-9010.91.4.777.

Maas, V. and Torres-Gonzalez, R. (2011) "Subjective Performance Evaluation and Gender Discrimination”. Journal of Business Ethics 101: 667-81, http://dx.doi. org/10.1007/510551-011-0763-7.

Manpower (2008) Kobiety na kierowniczych stanowiskach [Women in management positions]. Survey by Manpower Polska.

Martin, J. (2011) "Does Gender Inequality Ever Disappear?" in E. Jeanes, D. Knights and P. Martin (eds) Handbook of Gender, Work and Organization. Chichester: Wiley.

Neergaard, H., Hersby, M., Madsen, H., Ulhoi, J. and Madsen, M. (2008) "Revisiting the Think Manager-Think Male Syndrome in an Egalitarian Culture". Paper to the Academy of Management Conference, Anaheim, California.

Ngo, H., Foley, S., Wong, A. and Loi, R. (2003) "Who Gets More of the Pie? Predictors of Perceived Gender Inequity at Work". Journal of Business Ethics 45 (3): 227-41, http://dx.doi.org/10.1023/a:1024179524538.

Powell, G. and Greenhaus, J. (2010) "Sex, Gender and the Work-to-Family Interface: Exploring Negative and Positive Interdependencies". Academy of Management Journal 53 (3): 513-34, http://dx.doi.org/10.5465/amj.2010.51468647.

Sappleton, N. and Takruri-Rizk, H. (2008) "The Gender Subtext of Science, Engineering, and Technology (SET) Organizations: A Review and Critique”. Women's Studies 37 (3): 284-316, http://dx.doi.org/10.1080/00497870801917242.

Schein, V. E. (1973) "The Relationship between Sex Role Stereotypes and Requisite Management Characteristics”. Journal of Applied Psychology 57 (2): 95-100, http:// dx.doi.org/10.1037/h0037128.

Schein, V. E. (1975) "Relationships between Sex Role Stereotypes and Requisite Management Characteristics among Female Managers". Journal of Applied Psychology 60 (3): 340-44, http://dx.doi.org/10.1037/h0076637.

Schminke, M. (2001) "Considering the Business in Business Ethics: An Exploratory Study of the Influence of Organizational Size and Structure on Individual Ethical Predispositions". Journal of Business Ethics 30 (4): 375-90, http://dx.doi. org/10.1023/a:1010793308837.

Smith, N., Smith, V. and Verner, M. (2013) "Why Are So Few Females Promoted into CEO and Vice President Positions? Danish Empirical Evidence, 1997-2007". Industrial and Labor Relations Review 66 (2): 380-408.

Tomlinson, J. (2011) "Gender Equality and the State: A Review of Objectives, Policies and Progress in the European Union". The International Journal of Human Resource Management 22 (8): 3755-74, http://dx.doi.org/10.1080/09585192.2011.622923.

Turner, J., Hogg, M., Oakes, P., Reicher, S. and Wetherell, M. (1987) Rediscovering the Social Group: A Self-Categorization Theory. Cambridge: Basil Blackwell.

Valentova, M., Krizova, I. and Katrnak, T. (2007) "Occupational Gender Segregation in the Light of the Segregation in Education: A Cross-national Comparison”. IRISS Working Paper, Volume 2007-04.

Weinberger, C. (2011) "In Search of the Glass Ceiling: Gender and Earnings Growth among US College Graduates in the 1990s". Industrial and Labor Relations Review 64 (5): 949-80. 
Witkowska, D. (2013) “Gender Disparities in the Labor Market in the EU”. International Advances in Economic Research 19: 331-54, http:/dx.doi.org/10.1007/s11294-0139431-2.

Hausmann, R., Tyson, L. and Zahidi, S. (eds) (2012) “The Global Gender Gap Report”. Geneva: World Economic Forum.

Yap, M. and Konrad, A. M. (2009) "Gender and Racial Differentials in Promotions: Is There a Sticky Floor, a Mid-level Bottleneck, or a Glass Ceiling?" Industrial Relations 64 (4): 593-619, http://dx.doi.org/10.7202/038875ar.

\section{Abstract \\ Determinanty pionowej i poziomej segregacji ze względu na pleć w miejscu pracy w Polsce}

Celem artykułu jest dokonanie analizy czynników wpływających na skalę segregacji zawodowej w wymiarze pionowym i poziomym w Polsce. Przedstawiono rezultaty badań jakościowych i ilościowych przeprowadzonych wśród polskich pracowników. Dane pochodzą z projektu badawczego poświęconego społecznej odpowiedzialności biznesu z perspektywy pracownika. Łącznie przeprowadzono 90 pogłębionych wywiadów indywidualnych (IDI) oraz 1000 wywiadów telefonicznych wspomaganych komputerowo (CATI) na reprezentatywnej próbie polskich pracowników. Analizie poddano grupę zmiennych związanych ze statusem społeczno-demograficznym respondenta, cechami jego organizacji i zinternalizowanymi normami i wartościami. Wyniki badań pokazują, że większość zaobserwowanych przypadków dyskryminacji jest spowodowana normami i wartościami kulturowymi polskiego społeczeństwa, które decydenci i pracownicy organizacji internalizują od wczesnych etapów procesu socjalizacji.

Słowa kluczowe: dyskryminacja ze względu na płeć, segregacja pionowa, segregacja pozioma, Polska. 